\title{
HYDROGEOLOGICAL RESEARCH AS A BASIS FOR THE PREPARATION OF THE PLAN OF MONITORING GROUNDWATER CONTAMINATION - A CASE STUDY OF THE STARA VAS LANDFILL NEAR POSTOJNA (SW SLOVENIA)
}

HIDROGEOLOŠKE RAZISKAVE KOT OSNOVAZA IZDELAVO NAČRTA MONITORINGA ONESNAŽENOSTI PODZEMNIH VOD PRIMER ODLAGALIŠČA STARA VAS PRI POSTOJNI (JZ SLOVENIJA)

METKA PETRIČ́1 $\&$ STANKA ŠEBELA ${ }^{1}$

${ }^{1}$ Karst Research Institute ZRC SAZU, Titov trg 2, SI-6230 Postojna, Slovenija, e-mail: petric@zrc-sazu.si, sebela@zrc-sazu.si 

Metka Petrič \& Stanka Šebela: Hydrogeological research as a basis for the preparation of the plan of moni-
toring groundwater contamination: A case study of the Stara vas landfill near Postojna (SW Slovenia)

For the present 9 landfills on karst are still active in Slovenia, among them also the Stara vas landfill near Postojna. As strong fissuration of the rock base and very good permeability is typical for karst areas, the waste waters from the landfills particularly endanger the groundwater. The capacity of natural filtration in karst is very low and the dimension of possible negative impact is very high. The actual legislation regulates the performance of operational monitoring, a part of which is also the measurement of parameters of contamination of groundwater by hazardous substances, if they are in the area of influence of the landfill. Preparation of the monitoring plan is based on adequate hydrogeological researches. Besides basic geological and hydrogeological data also the results of tracer tests were used in the case study of the Stara vas landfill. Additionally, the detailed tectonic-lithological mapping in the scale 1:5000 was performed in the narrow area of the landfill. Based on defined characteristics of underground water flow and in accordance with the regulations 3 monitoring points inside (Malenščica and Vipava springs, Fužina cave) and one point outside the area of influence of the landfill (Matijeva jama cave) were selected. The monitoring plan for the observation of water quality and capacity was suggested.

Key words: landfill, monitoring of groundwater, Stara vas, Postojna, Slovenia.

Izvleček

UDK: 556.3:504.054(497.4)

Metka Petrič \& Stanka Šebela: Hidrogeološke raziskave kot osnova za izdelavo načrta monitoringa onesnaženosti podzemnih vod: primer odlagališ̌ca Stara vas pri Postojni (JZ Slovenija)

V Sloveniji je na krasu trenutno aktivnih devet odlagališč komunalnih odpadkov, med drugimi tudi Stara vas pri Postojni. Ker je za kraška območja značilna močna razpokanost kamninske osnove in zelo dobra prepustnosti, izcedne vode z odlagališč še posebej ogrožajo podzemno vodo. Sposobnost naravne filtracije je v krasu majhna, obseg možnega negativnega vpliva pa zelo velik. Sedaj veljavna zakonodaja predpisuje obratovalni monitoring, del katerega je tudi merjenje parametrov onesnaženosti podzemnih vod z nevarnimi snovmi, če so v vplivnem območju odlagaličča. Temelj za izdelavo načrta monitoringa so ustrezne hidrogeološke raziskave. Za primer Stare vasi smo poleg osnovnih geoloških in hidrogeoloških podatkov uporabili še rezultate sledilnih poskusov, ožje območje odlagališča pa smo podrobno tektonsko-litološko kartirali v merilu 1:5000. Na osnovi ugotovljenih značilnosti pretakanja vode v podzemlju in v skladu s predpisi smo določili 3 točke monitoringa znotraj (izvira Malenščica in Vipava, jama Fužina) in eno izven vplivnega območja odlagališča (Matijeva jama) ter določili način spremljanja kakovosti vode in izdatnosti.

Ključne besede: odlagališče odpadkov, monitoring podzemnih vod, Stara vas, Postojna, Slovenija. 


\section{INTRODUCTION}

The Slovene legislation regarding the wastes has the form and structure similar to the one of the European Union. The basic regulation is Rules on Waste Management (Official Journal of the Republic of Slovenia - OJ RS 84/98, 45/00 and 20/01). Two regulation groups supplement it. The first one deals with different kinds of wastes, and the second one with conditions for operation of the facilities for waste management.

The reality of realization of the placed legislation is less satisfying. One of the reasons is because in the transition period there is the possibility for progressive application to the new requests.

According to the data collected in the State of Environment Report (PSO 2002) that was prepared in 2002 by the Ministry of the Environment and Spatial Planning of the Republic of Slovenia, every year about $450 \mathrm{~kg}$ of wastes per resident are produced in Slovenia. According to the data from the year 2000 among 51 landfills of non-hazardous wastes, just 8 fulfilled the placed legislation, and 10 of them gradually approached the legislation. After the year 2008 just 17 of the existing landfills in Slovenia are supposed to continue to work.

The actual transitional period in legislation still permits the waste deposition and also the expansion of the landfills on the so-called risky areas (according to existing legislation it is not possible to plan the new landfills on such areas) to which also the karst belongs. Today we still have 9 landfills on the karst: Cerknica (Rakek-Pretržje), Črnomelj (Vranoviči), Ilirska Bistrica (Jelšane), Kočevje (Mozelj), Logatec (Ostri vrh), Metlika (Bočka Metlika), Postojna (Stara vas), Ribnica (Mala Gora) and Sežana (Fig. 1). For all landfills the closing as well as their further maintenance and protection is foreseen. The new regional centers for waste management placed on better locations with modern technological solutions will take over the older landfills.

\section{LANDFILLS ON KARST}

The strong fissuration of the rock base and good permeability is typical for karst areas. The rainwater together with harmful substances enters quickly into the aquifer. In the underground the water runs quickly through the karst channels and opened fissures. From the entrance point the water rapidly spreads in different directions also towards the more distant karst springs. Due to the flow in the underground it is difficult to determine its directions and characteristics. The capacity of natural filtration in karst is very low and the dimension of possible negative influence very high. Because of this the landfills on karst are particularly problematic being a possible source for pollution of groundwater. More dangerous than the wastes is the percolation of wastewater into the karst underground. The source of waste waters are partly the wastes themselves, but higher quantities are the result of washing out of waste substances by precipitation that come in the contact with landfill. Due to various content of wastes also the resulting leachates are complex liquids with high content of salts, metals and organic compounds (Drew \& Hötzl 1999). Landfills contribute to a more or less continuous input of contaminants over long periods.

Still the chemical impact of waste on karst waters was often relatively small. Although concentrations of alkali ions, chlorides or sulphates were increased, most of the waters in the area of influence were remaining within the drinking water standard. One of the reasons is the type of nonhazardous waste. It is also due to the generally oxidizing and neutralizing conditions found in many karst waters as well as to the attenuation affect at the spring outflow, which rapidly dewaters even 
large catchment areas (Drew \& Hötzl 1999). But the use and disposal of toxic materials is growing, therefore also the danger of pollution is increasing.

The insufficient data are representing the problem for the estimation about negative influence of the landfill on the karst waters. In the past in Slovenia the planed measurements about contamination of groundwater in the area of influence mostly haven't been performed. Because those data are missing the contamination problematic generally haven't been adequately treated. But the actual Rules on landfill waste tipping (OJ RS 5/00) in the Article 49 regulate the performance of operational monitoring and in Annex 8 define its dimension and the way of performance. One part of the monitoring is also the measurement of parameters of contamination of groundwater by hazardous substances, if they are in the impact area of the landfill. They are determined by Rules on monitoring the pollution of groundwater with hazardous substances (OJ RS 5/00).

The landfill manager has to acquire the program of monitoring for the groundwater, which needs to describe hydrogeological conditions and characteristics of groundwater flow, conditions of groundwater before the construction of landfill, target hydrogeological zones, characteristics of the contamination source, the description of the selection, the plan and the test of monitoring points, the definition of monitoring parameters and the frequency of their measurements. Ministry of the Environment and Spatial Planning has to confirm the program before its beginning. All existing landfill are now preparing such programs. Also the landfills that will be closed need such program, because the monitoring will have to continue also after the closure of the landfills.

\section{THE CHARACTERISTICS OF THE STARA VAS LANDFILL}

\section{Basic information}

Stara vas landfill near Postojna in south-western Slovenia is one of still active landfills on karst. It is situated approximately $700 \mathrm{~m}$ south-south-western from the village Stara vas on the western edge of the Javorniki karst massif at the altitude around $580 \mathrm{~m}$. According to the information supplied by its manager Publicus d.o.o. the landfill was opened in 1969, and after reconstruction it was activated again in 1999. Yearly around $8500 \mathrm{t}$ of non-hazardous waste from the municipalities Postojna and Pivka is deposited. The landfill is planned to contain up to $90.000 \mathrm{~m}^{3}$ of compacted waste. Waste waters are collected and transported to the central water treatment plant of Postojna. Surface waters, which are not in contact with waste, are drained into a sink. According to the plans the procedures of closure will begin in 2008. But even before, it is necessary to set the monitoring system, which also includes measurements of parameters of groundwater pollution with harmful substances. Preparation of the monitoring plan is based on adequate hydrogeological researches, because it is necessary to know the characteristics of groundwater flow from the landfill in order to choose representative monitoring points and effective monitoring plan.

\section{Geological conditions}

The wider area of the landfill is built of Upper Cretaceous limestones $\mathrm{K}_{2}^{2,3}$. According to Geological map of Postojna (Buser et al. 1967) we have grey rudist limestone with not well determined radiolitid fauna and non-typical micro fauna. Rižnar (1997) classified those limestones as Coniacian-Campanian $\mathrm{K}_{2}^{4,5}$. After Rižnar (1997) the landfill is situated in light grey to brown micritic limestones with pieces of rudists and foraminifera that alternate with the layers of rudist lumachella. 
In between there are seldom layers of pelagic limestone, calcarenite and chert lenses in the higher parts. The flysch basal sediments (breccia with pieces of Paleocene limestone with conglomerate and marl inbeds $-\mathrm{Pc}_{2}, \mathrm{E}_{1}$ ) are younger than Cretaceous limestones. The following is Eocene flysch (E - alternation of marls and sandstone). The youngest are Quaternary sediments, alluvium.

In the tectonic sense the studied area is part of the Snežnik thrust sheet. In Pivka valley there are places where the thrust contact between Upper Cretaceous limestone and Eocene flysch is well visible, there are areas that represent erosional border and areas with normal transition between limestone, basal flysch sediments $\left(\mathrm{Pc}_{2}, \mathrm{E}_{1}\right)$ and flysch.

Regarding the field geological mapping of Rižnar (1997) and Placer (1994/95) the inner fault zone of Predjama fault is situated about $2 \mathrm{~km}$ north from the Stara vas landfill. The fault represents one of the most expressed regional Dinaric faults in Pivka valley. Along the fault dextral horizontal movement is supposed.

\section{Hydrogeological characteristics}

Upper Cretaceous limestones of Javorniki massif are well karstified and form the main karst aquifer with dominant groundwater flow (Fig. 2). On its western side in the lower Pivka valley surface drainage net is developed on less permeable Quaternary alluvial sediments and Eocene flysch. In its upper stream the Pivka river flows partly on the surface and partly underground along the western edge of the Javorniki mountains. At high waters several karst springs are activated along it and also

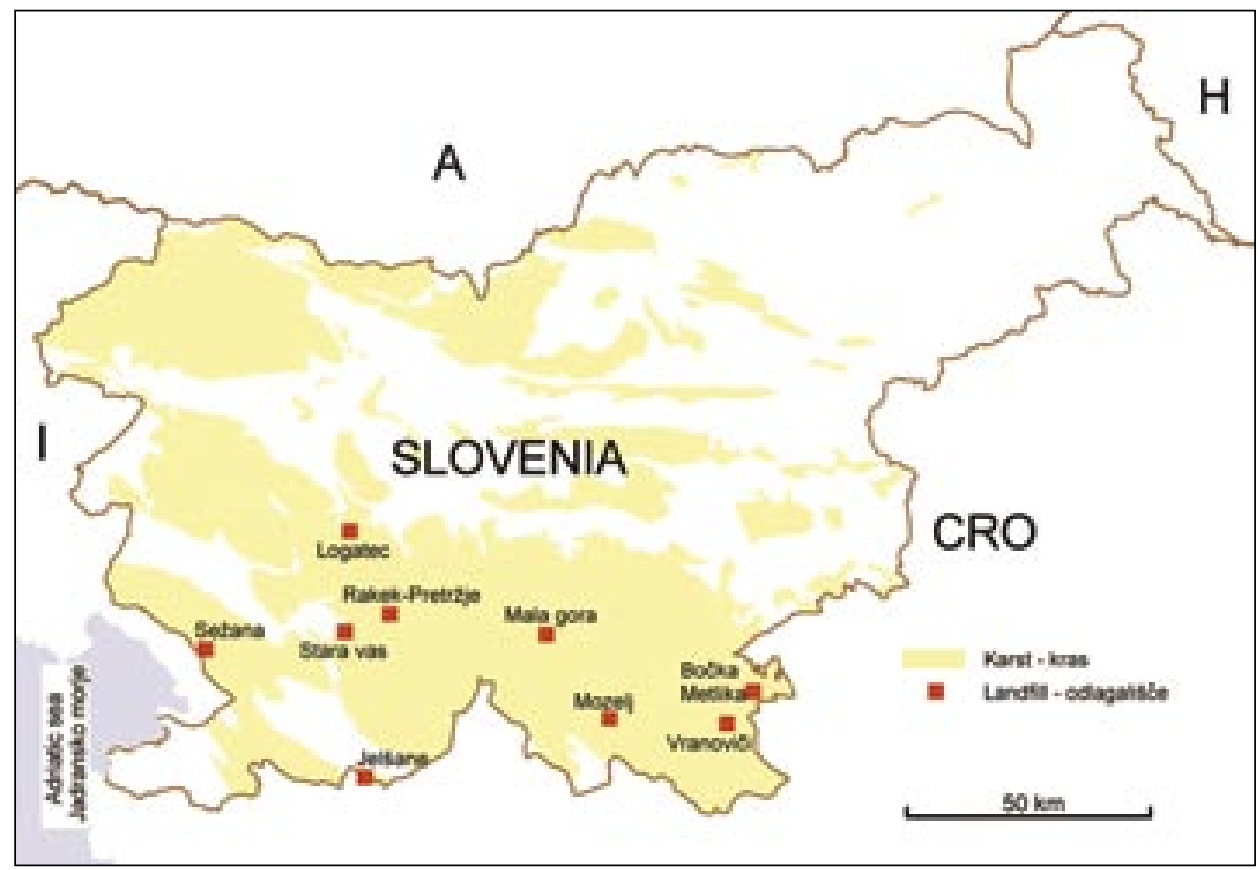

Figure 1: Landfills on karst in Slovenia.

Slika 1: Odlagališča na krasu v Sloveniji. 
Pivka intermittent lakes are filled with water. During low waters the water table decreases below the river bed and Pivka sinks underground through several ponors. In general the thickness of flysch in the Pivka valley is relatively small and karst aquifer is developed also below it. Close connection between surface drainage net and underground karst flow is characteristic for the whole area.

On northern and eastern side Javorniki are bordered by the Planinsko polje, Cerkniško polje and Rakov Škocjan. These are typical karst features for which surface flow in connection with underground flow in surrounding massifs is characteristic. The bottom of Planinsko polje and Cerkniško polje is built by Upper Triassic dolomite, which is less permeable than limestones. Both poljes are cut by the fault zone of the Idrija fault, which acts as hydrogeological barrier. Along it karst waters outflow through several springs, flow on the surface across the polje, and sink again underground.

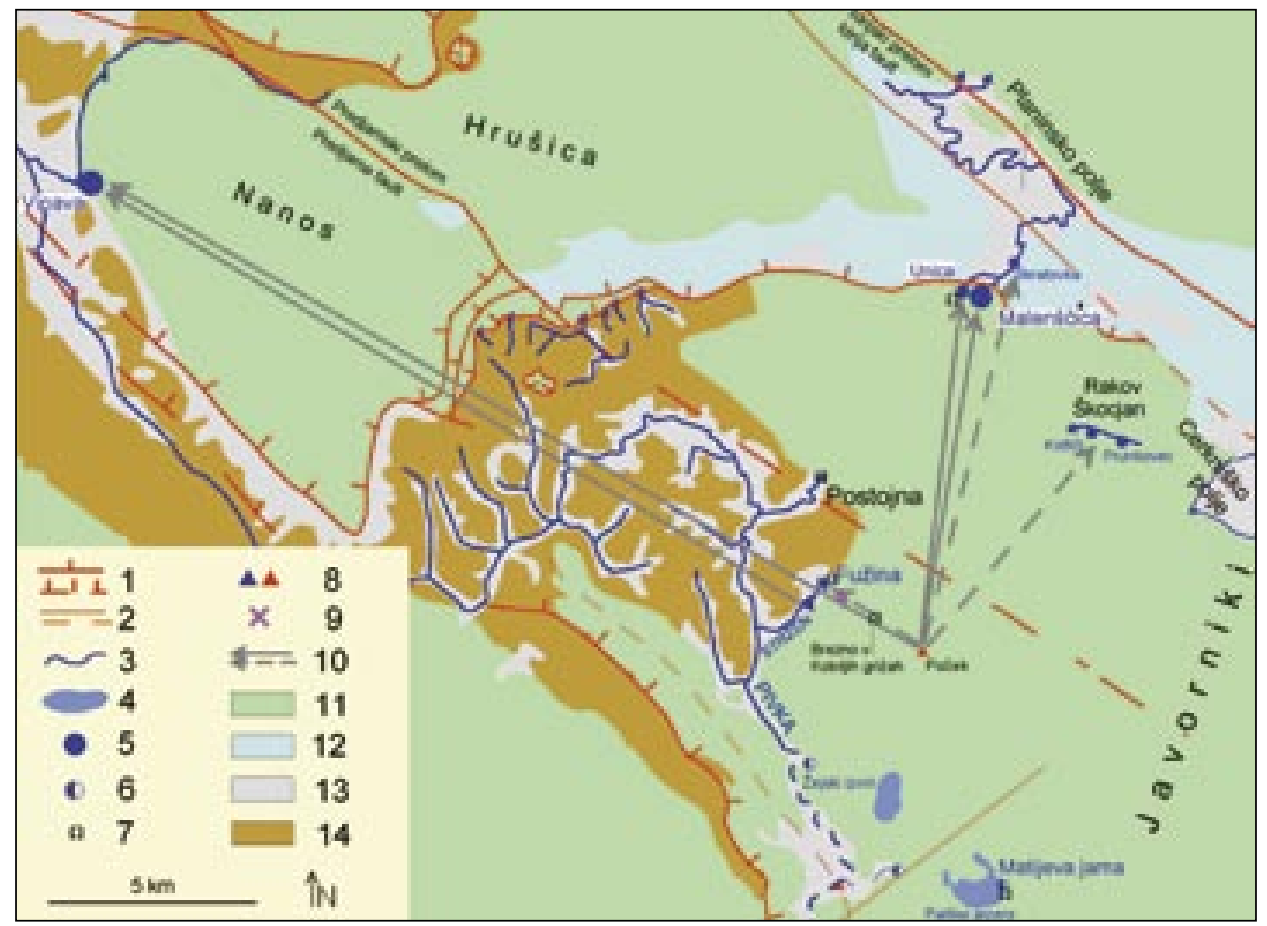

Figure 2: Hydrogeological map of the broader area of the landfill with the results of tracer tests (Legend: 1.Visible and covered thrust plane, 2. Visible and covered fault, 3. Surface stream, 4. Intermittent lake, 5. Permanent spring, 6. Intermittent spring, 7. Karst cave, 8. Ponor or injection point, 9. Landfill, 10. Main and secondary underground water connection, proved by tracer test, 11 . Karst aquifer, 12. Fissured aquifer, 13. Porous aquifer, 14. Very low permeable rocks).

Slika 2: Hidrogeološka karta šiř̌ega območja odlagališča z rezultati sledenj (Legenda: 1. vidna in pokrita narivnica, 2. viden in pokrit prelom, 3. površinski tok, 4. presihajoče jezero, 5. stalni izvir, 6. občasni izvir, 7. kraška jama, 8. ponor ali točka injiciranja, 9. odlagališče, 10. s sledenjem dokazana glavna in stranska podzemna vodna zveza, 11. kraški vodonosnik, 12. razpoklinski vodonosnik, 13. medzrnski vodonosnik, 14. zelo slabo prepustne plasti). 
The Rakov Škocjan area is built by Cretaceous limestone, which is in the valley of the surface stream Rak covered by Holocene sediments.

In the south Javorniki traverse into the Snežnik mountain. Here is the watershed between Pivka and rivers Reka, Riječina, and Kolpa, but due to specific characteristics of karst and the lack of adequate data it is practically impossible to define its position more precise. It is not essential for this research because according to the hydrogeological conditions, water table oscillations and results of tracer tests we can conclude that the groundwater flow from the landfill doesn't reach this watershed.

\section{Springs in the area of influence of the landfill}

To define the springs in the area of influence of the landfill also the results of tracer tests (Jenko 1959, Habič 1989, Kogovšek 1999, Kogovšek et al. 1999, Kogovšek \& Petrič 2004) were considered besides basic geological and hydrogeological characteristics. The main direction of underground flow from the karst aquifer of Javorniki is towards the springs at the southern border of the Planinsko polje. The most important among them is the Malenščica spring, which is captured for the water supply of the municipalities Postojna and Pivka. Its discharges range between $1.1 \mathrm{~m}^{3} / \mathrm{s}$ and $9.9 \mathrm{~m}^{3} / \mathrm{s}$, and the mean discharge is $6.7 \mathrm{~m}^{3} / \mathrm{s}$ (Kolbezen \& Pristov 1998). The Unica spring is bigger at high waters with discharges almost $100 \mathrm{~m}^{3} / \mathrm{s}$, but smaller in dry periods with only several hundred liters per second (Gospodarič \& Habič 1976). Downstream the confluence of Malenščica and Unica there is an intermittent spring Škratovka with discharges up to $7 \mathrm{~m}^{3} / \mathrm{s}$. In Rakov Škocjan karst waters outflow mainly through two springs: Kotliči and Prunkovec.

Also underground flow below the flysch of the Pivka basin towards the Vipava spring was proved by tracing. The Vipava spring with discharges from 0.7 to $70 \mathrm{~m}^{3} / \mathrm{s}$ and mean discharge $6.78 \mathrm{~m}^{3} / \mathrm{s}$ (Kolbezen \& Pristov 1998) is captured for the water supply of the upper Vipava valley.

The nearest to the landfill is the Fužina spring near Stara vas (named also Velika Fužina). It is active only during high waters otherwise permanent water is deeper in the Fužina cave. The main outflow is through the lowest entrance shaft, but water can outflow also at several locations in the field above the cave. Spring water forms the Stržen brook and flows on the surface towards the Pivka river. In the period of heavy rain in February 1957 the discharge of $2.6 \mathrm{~m}^{3} / \mathrm{s}$ was measured (according to data of the Cave register).

The Žejski izviri spring is the strongest and the most durable spring along the Pivka river. It is active around 6 months per year, with discharges up to $6 \mathrm{~m}^{3} / \mathrm{s}$.

\section{Karst caves with water flow and exploration boreholes}

Also natural object such as karst caves or already existing exploration boreholes are very suitable points of monitoring. The nearest to the landfill is the Fužina cave. Around $125 \mathrm{~m}$ long and 14 $m$ deep cave has permanent water flow, and at high waters it acts as the Fužina karst spring. In the frame of the researches for the water supply approximately $100 \mathrm{~m}$ deep borehole was drilled near the cave. In a short period of observation water levels between $513 \mathrm{~m}$ and $525 \mathrm{~m}$ a.s.l. were measured in the borehole (Habič 1989). The borehole is now plugged and water sampling in it is not possible. The same situation is with two exploration boreholes drilled near the Brezno v Kobiljih grižah cave and the Žejski izviri spring.

The entrance to the Brezno v Kobiljih grižah cave is approximately $1 \mathrm{~km}$ south-eastern from the 
landfill. Around $72 \mathrm{~m}$ deep shaft has permanent water at the bottom. The water level ranges between $514 \mathrm{~m}$ and $529 \mathrm{~m}$ a.s.l. (Habič 1989).

Outside the area of influence of the landfill is $36 \mathrm{~m}$ deep and $50 \mathrm{~m}$ long Matijeva jama cave at the Palško jezero intermittent lake, which functions as an estavelle. In dry periods water table in it lowers $40 \mathrm{~m}$ below the surface, also below the Pivka river bed, and at high waters it acts as a spring and fills-up the lake.

In the years 1982, 1988 and 1989, water table in boreholes near Stara vas, Brezno v Kobiljih grižah cave, Žejski izviri spring, and Matijeva jama cave was observed (Habič 1989). Water level oscillations in first two mentioned boreholes were rather parallel. Higher water table in the borehole near the Brezno v Kobiljih grižah cave indicates groundwater flow from this point, below the landfill and further towards Stara vas. Of course, also in the landfill area deeper underground water flow mainly towards the springs of Malenščica and Vipava is presumed. Comparisons between the water levels in the boreholes near the Žejski izviri spring and the Brezno v Kobiljih grižah cave points-out the possibility of the groundwater flow from the landfill area towards the Žejski izviri spring during low waters, but this connection was not confirmed by tracer test at Poček in 1997 (Kogovšek 1999).

\section{Geological and hydrogeological conditions in the narrow area of the landfill}

With the purpose to estimate the characteristics of infiltration and percolation of water in the area of the landfill the detailed tectonic-lithological mapping in the scale 1:5000 was performed (Fig. 3). Most of the studied area represents Upper Cretaceous limestones $\mathrm{K}_{2}^{2,3}$ (Buser et al. 1967) respectively $\mathrm{K}_{2}{ }^{4,5}$ (Rižnar 1997). Just the most western part represents alluvium (Quaternary). Some $10 \mathrm{~m}$ south from the landfill the limestone beds are dipping towards SW with the angle of $20^{\circ}(250 / 20$, 230/20). Northeast from the landfill the dip direction of the bedding planes changes. Here we have the limestones dipping towards SE for $20^{\circ}$ (160/20). The thickness of the limestone beds is $0.7 \mathrm{~m}$ in the vicinity of the landfill. In limestone numerous rudists can be found and on the SW slope of Žerible about $1 \mathrm{dm}$ long chert lenses in limestone beds can be traced.

In the area west from the railway the thick-bedded limestone prevails $(280 / 20,280 / 30)$. In the contact area between limestone and alluvium the massive limestone appears (Figs. 3 and 4).

On the NW slope of Žerible the probable anticline was determined due to the difference in the bedding dip direction. The smaller fold with the cross Dinaric oriented axis dips towards the SW.

On the studied area we found two strong faults. The northern one is the same as was determined already by Rižnar (1997). The fault has Dinaric orientation and runs south from Stara vas, north from the road crossing the railway and north from Žerible. The fault is subvertical with $10-20^{\circ}$ curving in horizontal direction. The crushed zone along the fault is not wider than $2 \mathrm{~m}$. The fault is parallel with the northern Predjama fault (Placer 1994/95) that is situated out from the Figure 3.

Southern fault runs through the southern edge of the landfill. In the western part of the studied area it is subvertical, and close to the landfill dips for $70^{\circ}$ towards NE (20/70).

Besides faults more fissured, broken and fissured to broken zones were determined after the classification of Čar (1982). Fissured to broken zone with geological elements 40-50/80-90 is the most common. South from the landfill the fissures are dipping towards the NE for $80^{\circ}(40 / 80,50 / 80)$, and on the area of the landfill the fissures are subvertical. In fact we have a $300 \mathrm{~m}$ wide fissured to broken zone in Dinaric orientation, which is well permeable for water and runs directly across the Stara vas landfill. Besides the prevailing fissured to broken zones in Dinaric orientation (40/80, 
Metka Petrič \& Stanka Šebela: Hydrogeological research as a basis for the preparation of the plan of monitoring groundwater ...

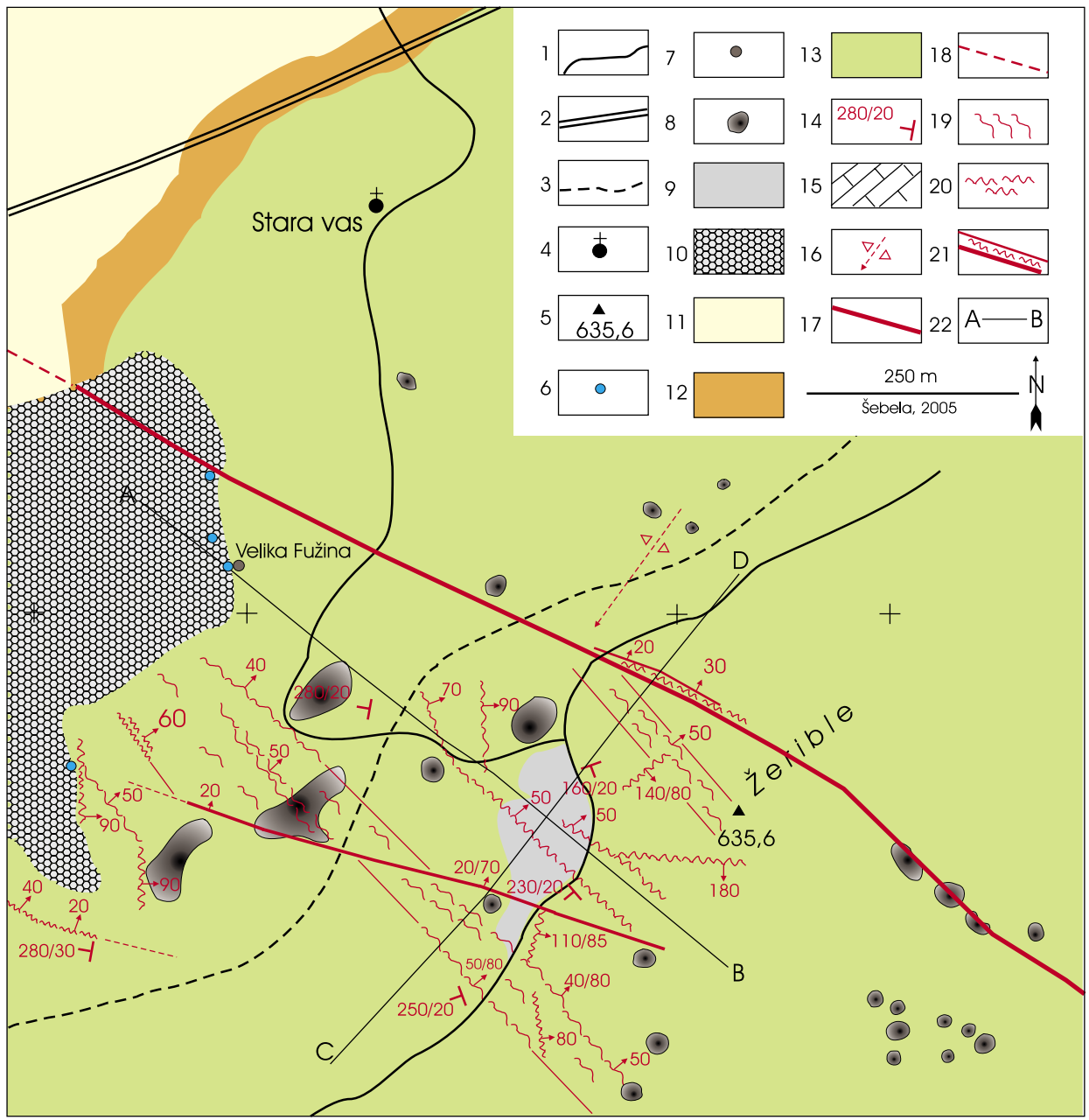

Figure 3: Map of detailed geological mapping of the Stara vas landfill. (Legend for figures 3 and 4: 1. Road, 2. Highway, 3. Railway, 4. Settlement, 5. Hill with above sea altitude in meters, 6. Intermittent spring, 7. Karst cave, 8. Doline, 9. Landfill, 10. Q alluvium, 11. Eflysch, 12. Pc $E_{2}$ (breccia with pieces of Paleocene limestone with conglomerate and marl layers), 13. $K_{2}^{2,3}$ limestone, 14. Dip direction and dip angle of limestone beds, 15. Dip direction of limestone beds in cross sections, 16. Supposed anticline axis that sinks towards $S W, 17$. Stronger fault, 18. Supposable continuation of the fault, 19. Fissured zone, 20. Broken zone, 21. Crushed zone, 22. Cross section).

Slika 3: Karta podrobnega geološkega kartiranja odlagališča Stara vas. (Legenda za sl. 3 in 4: 1. cesta, 2. avtocesta, 3. železnica, 4. naselje, 5. hrib z nadmorsko višino v metrih, 6. občasni izvir, 7. kraška jama, 8. vrtača, 9. odlagališče, 10. Q aluvij, 11. E fliš, 12. Pc $E_{2}$ (brě̃a s kosi paleocenskega apnenca in vložki konglomerata in laporja), 13. $K_{2}^{2,3}$ apnenec, 14. smer vpada in vpadni kot plasti apnenca, 15. vpad plasti apnenca v prečnih profilih, 16. domnevna os antiklinale, ki tone proti JZ, 17. močnejši prelom, 18. domnevno nadaljevanje preloma, 19. razpoklinska cona, 20. porušena cona, 21. zdrobljena cona, 22. prečni profil). 
$50 / 80,50,40)$ also other directions of broken zones $(110 / 85,100,140 / 80,180)$ were determined in the vicinity of the landfill.

Along the contact edge between Upper Cretaceous limestone and alluvium the subvertical broken zone with the dip direction $90^{\circ}$ is well expressed. Along the broken zone the well visible morphological edge, with more periodical springs, is developed.

Described geological conditions determine also hydrogeological characteristics. Due to a thin soil layer, well developed fissured and broken zones, well karstified rocks and therefore very good permeability the infiltration of precipitation and in it dissolved harmful substances is fast. In the vadose zone water flows fast through main drainage paths, but partly it is slower and can be re-

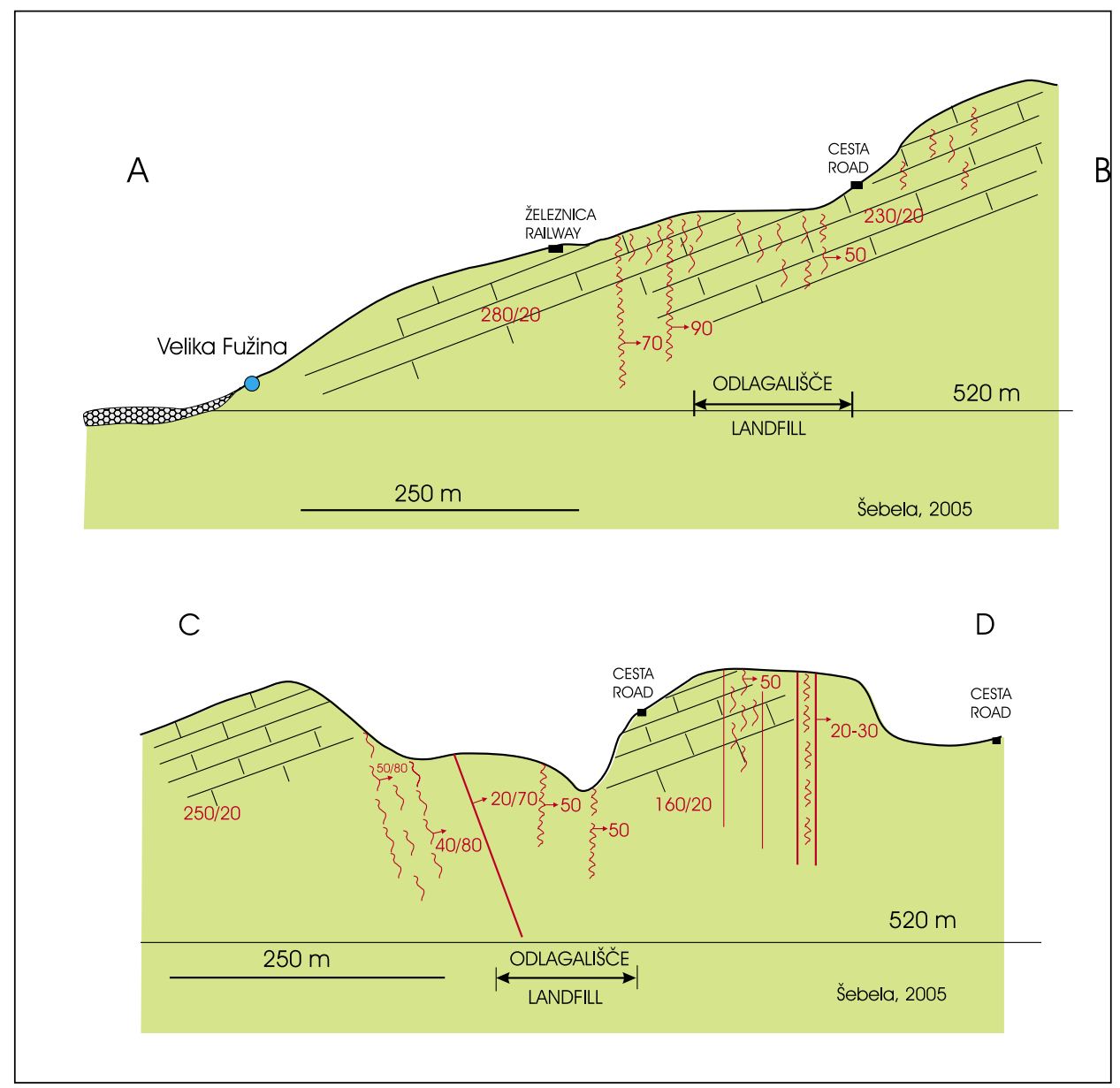

Figure 4: Cross-sections $A B$ and $C D$ across Stara vas landfill. The heights of cross sections are 3-times higher.

Slika 4: Prečna profila $A B$ in $C D$ čez odlagališče Stara vas. Višine prečnih profilov so $3 x$ povišane. 
tained for longer periods in less permeable zones. According to the measured water levels in before mentioned boreholes the thickness of the vadose zone below the landfill is estimated to be between $60 \mathrm{~m}$ and $75 \mathrm{~m}$ at different hydrological conditions. Results of previous researches indicate that after intensive precipitation infiltrated water can pass through the vadose zone already in several hours, but can be during dry periods also retained there for two to three months (Kogovšek et al. 1999). In the phreatic zone water flows mainly through karst fissures and channels in different directions towards the springs at the border. Characteristics and velocities of flow differ according to hydrological conditions. Based on tracer test underground flow towards the springs at the Planinsko polje (Malenščica, Unica, Škratovka) and Rakov Škocjan (Kotliči, Prunkovec), towards the springs along the Pivka river (Fužina), and also towards the Vipava spring in the Vipava valley was proved. Estimated apparent flow velocities were high $(0.2$ to $0.7 \mathrm{~cm} / \mathrm{s})$. Described characteristics indicate well permeable, unconfined aquifer with karst-fissured porosity.

Especially useful information for the preparation of the monitoring plan was gathered by the tracer test on Poček (Kogovšek 1999, Kogovšek et al. 1999, Kogovšek \& Petrič 2004). As the uranine was injected at the surface on the rock bottom of a smaller doline, it is easier to put the results in parallel with the conditions of leakage and groundwater flow of waste waters from the landfill. Unfortunately tracer test was performed at low waters therefore there was no direct estimation of the shortest possible time in which the pollution could reach the springs. Indirectly it can be inferred on the basis of observations of the breakthrough curves during further precipitation events. The tracer was first detected in the Fužina spring, then in the Malenščica spring, and at the latest in the Vipava spring due to a longest distance. Another important information obtained by tracing is that the increase of tracer concentration starts from half a day to several days behind the rising of discharge.

\section{Target hydrogeological zone}

Target hydrogeological zone is defined as the litho-stratigrafic unit in which groundwater can be polluted due to percolation of harmful substances from the landfill. In the observed area this is the aquifer with karst-fissured porosity of the Javorniki karst massif, which also includes karstified limestones below the flysch of Pivka valley, which are drained towards the Vipava springs. Infiltrated water party flows very fast through the unsaturated to the saturated zone and further towards karst springs at the border, but can also be temporarily stored in less permeable parts of the unsaturated zone. After each more intensive precipitation event more intensive washing out of contaminants from the landfill is possible, as well as flushing out of previously stored polluted water from vadose zone below the landfill deeper into karst and further towards karst springs. In observed area the main direction of underground flow is towards north to the springs at the Planinsko polje, and towards north-west to the Fužina spring and further below the flysch of Pivka valley to the Vipava spring.

\section{Data on water quality in the area of influence of the landfill}

On landfills in Slovenia the monitoring of waste waters is regularly performed. According to 4 measurements in the year 2000 at the Stara vas landfill (IVZ 2000) majority of parameters were inside the normative values, only in individual samples concentrations of adsorbable organic halogens and ammonium nitrogen were exceeded.

On the other hand, the monitoring of the quality of karst waters in the influence area of the landfill was not obligatory in the past, therefore only very few data on it exist. The water quality is regularly 
monitored only on springs, which are captured for the water supply. In the observed area such are the springs of Malenščica and Vipava, which are both included also in the regular monitoring performed by the Ministry of the Environment and Spatial Planning (Monitoring kakovosti izvirov 2001-2002). Problem of such monitoring is small number of samples, so that it is not possible to get a complex picture of water quality at different hydrological conditions. Just to get some general information the results of analysis from September 2001 at low waters and from October 2002 at high waters are compared. For the springs of Malenščica in Vipava the physico-chemical parameters are inside the normative values, but both springs are bacteriologically polluted. Nevertheless, by basic water treatment both springs are suitable for drinking. As water is within the standards, slightly increased concentrations of some chemical parameters are not sufficient reason to inquiry for the sources of pollution. Such investigations are difficult also due to the fact that the recharge areas of both springs are very big and therefore there is a large number of possible sources of pollution.

In other springs in the influence area of the landfill water quality measurements are only rare and sporadic. Individual measurements were performed in the frame of different research project, which were not aimed at the evaluation of harmful influences of the landfill. The Fužina spring was observed during a water wave in May 1991. Lower concentrations of nitrates and sulphates at the end of recession period in comparison with their concentrations before the start of precipitation event probably indicate more intensive washing out of pollution from the landfill at the beginning of the observation period (Kogovšek 1996).

Even fewer data exist from the period before the activation of the landfill in 1968. Only individual samples were analysed, therefore it is not possible to assess the natural state before the construction of the landfill.

Such lack of adequate water quality data even emphasizes the need of establishing monitoring of groundwater in the influence area of the Stara vas landfill.

\section{PROPOSAL OF THE MONITORING PLAN}

In the Rules on monitoring the pollution of groundwater with hazardous substances (OJ RS $5 / 00$ ) boreholes are defined as the main observation points. But on karst their efficiency is not high enough, so instead the observation at natural objects is recommended. For the landfill Stara vas they were chosen based on above described hydrogeological researches. The most useful were the results of tracer tests. Although in none of them injection point was in the area of landfill, obtained results were good indicator of the characteristics of groundwater flow.

As monitoring points two drinking water sources Malenščica and Vipava were chosen. Underground water connection of both springs with the landfill was proved by tracing. Both companies, which manage the water supply from the springs, are obliged to monitor water quality, and it is advantageous to use their data also for the monitoring of the influence of the landfill. At both springs discharges are measured by the Environmental Agency of the Republic of Slovenia.

As the nearest spring connected with the landfill also the Fužina spring is proposed as the point of monitoring. During high waters sampling at the spring is possible, otherwise it is necessary to sample the water flow in the cave. To get the data about capacity the monitoring of water levels in the cave has to be organized.

According to the regulations also one monitoring point outside the area of influence should be 
set. For the Stara vas landfill the Matijeva jama cave is suggested. It is outside the area of influence and in its vicinity there are no significant sources of pollution. Water will have to be sampled in the cave, only during high waters samples can be taken at the outflow from the cave. The estimation of capacity will be possible by the measurement of water levels in the cave.

In Annex 8 of the Rules on landfill waste tipping (OJ RS 5/00), which regulates the performance of operational monitoring, measurements of water table once monthly (more frequently in aquifers with bigger oscillations of water table) and measurements of the parameters of contamination of groundwater at least each 6 months are prescribed. In the annexes of the Rules on monitoring the pollution of groundwater with hazardous substances (OJ RS 5/00) physical as well as basic and indicative chemical parameters, which have to be monitored, are defined.

In accordance with this basic frame and studied characteristics of the karst aquifer in the area of influence of the Stara vas landfill the monitoring plan was prepared. On all 4 monitoring points sampling for physico-chemical analysis four times yearly at different hydrological conditions (in summer dry period, after first autumn precipitation, at high waters in autumn, during increase of discharges in spring) is proposed.

But by such seasonal sampling occasional problems with water quality can be overlooked. After stronger precipitation events more intensive washing out of contaminants from the landfill as well as flushing out of previously stored polluted water from the vadose zone below the landfill can be expected, therefore additional, more detailed sampling during a selected water wave after first

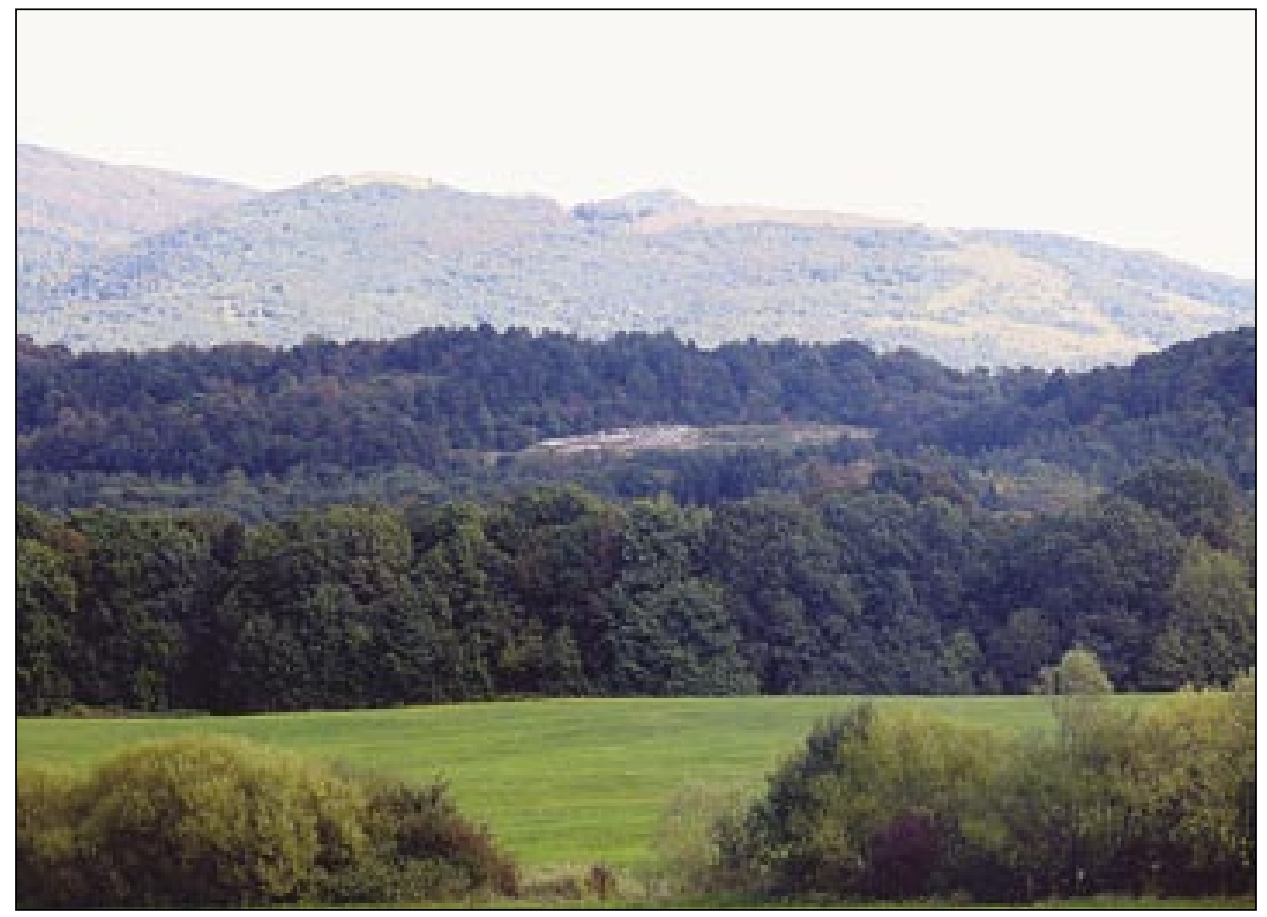

Figure 5: Stara vas landfill (Photo by S. Šebela).

Slika 5: Odlagališče Stara vas (Foto: S. Šebela). 
intensive autumn rains is suggested. In the period from the beginning of the increase of discharge, through the discharge peak sampling once a day and then in the recession phase back to the initial state sampling each two days is proposed. In this way around 10 to 15 samples would be collected. By comparison of their basic physico-chemical characteristics only representative samples can be selected for a complete water quality analysis.

For karst aquifers also continuous monitoring of discharges is suggested. At the springs of Malenščica and Vipava discharges are regularly measured by the Environmental Agency. Additionally, equipment for continuos measurement of water levels should be installed in the Fužina cave and in the Matijeva jama cave. During high waters, when also springs from both caves are active, the discharges of both springs should be measured.

In the case of detection of pollution an immediate reaction is necessary. Otherwise, yearly reports about the performance and results of monitoring have to be prepared. The monitoring points and measurement equipment should be regularly controlled in the field. Also measured values and results of analyses should be mutually compared and evaluated according to known characteristics of observed karst aquifer.

As especially bigger springs have larger recharge areas with different pollution sources, it is important to compare the results of physico-chemical analysis of water samples from all 4 sampling points in order to evaluate obtained results and interpret possible occurrences of pollution. Additional information can be obtained by comparison of data on water quality with hydrological conditions. Based on all gathered data it will be possible to improve the performance and efficiency of monitoring.

\section{CONCLUSIONS}

The Stara vas landfill is, in the geological sense, situated inside the fissured to broken zone that is well permeable. Also the strong fault that runs in the southern part of the landfill doesn't represent the sufficient hydrogeological barrier. The water can rapidly percolate from the surface to the underground, and than follows the well-developed karst drainage net towards the springs at the border. Among them Malenščica and Vipava springs are important sources for regional water supply. The proposed monitoring will besides those two springs include also the Fužina spring, which is the closest spring to the landfill. As it is active only at high waters, sampling and measurements will be mainly organized in the nearby Fužina cave. The connection of all three springs with the landfill derives from the known geological conditions, hydrological characteristics and results of tracer tests. The latter are also the base for assessment of the time and quantitative distribution of pollution of the springs in the area of influence of the landfill. Additionally, the Matijeva jama cave is proposed as the monitoring point outside the area of influence.

In accordance with legislation the proposed basic monitoring on all suggested sampling points will be performed four times per year during the different hydrological conditions. Due to the specific characteristics of karst aquifers the additional monitoring of typical autumn water wave is proposed. The physical, as well as basic and indicative chemical parameters that need to be included into the monitoring are determined by Rules on monitoring the pollution of groundwater with hazardous substances. Besides the quality the measurements of capacity are foreseen. The discharge measurements of Malenščica and Vipava are regularly performed by the Environmental Agency. For the 
water monitoring in the caves Fužina and Matijeva jama we suggest installing the instrument for continuous monitoring of water level oscillations. The permanent supervision of the monitoring net, as well as the comparison of the obtained results will help to improve the performance and efficiency of monitoring.

\section{REFERENCES}

Buser, S. \& K. Grad \& M. Pleničar, 1967: Osnovna geološka karta SFRJ, list Postojna 1:100000.Zvezni geološki zavod, Beograd.

Čar, J., 1982: Geološka zgradba požiralnega obrobja Planinskega polja.- Acta carsologica SAZU 10 (1981), 75-105, Ljubljana.

Drew, D. \& H. Hötzl, (Eds) 1999: Karst Hydrogeology and Human Activities.- A.A. Balkema, 322 pp, Rotterdam, Brookfield.

Gospodarič, R. \& P. Habič, 1976: Underground water tracing. Investigations in Slovenia 1972-1975.Institute for Karst Research, 312 str, Ljubljana.

Habič, P., 1989: Kraška bifurkacija Pivke na jadransko črnomorskem razvodju.- Acta carsologica, 18, 233-264, Ljubljana.

IVZ, 2000: Obratovalni monitoring odpadnih voda podjetja Publicus - deponija Postojna-leto 2000.Inštitut za varovanje zdravja, Ljubljana, 20 str.

Jenko, F., 1959: Poročilo o novejših raziskavah podzemeljskih voda na slovenskem krasu.- Acta carsologica, 2, 209-227, Ljubljana.

Kogovšek, J., 1996: Kako smetišča ogrožajo kakovost kraške vode.- Annales, 9/96, 111-114, Koper.

Kogovšek, J., 1999: Nova spoznanja o podzemnem pretakanju vode v severnem delu Javornikov (Visoki kras).- Acta carsologica, 28/1, 161-200, Ljubljana.

Kogovšek, J. \& M. Knez \& A. Mihevc \& M. Petrič \& T. Slabe \& S. Šebela, 1999: Military training area in Kras (Slovenia).- Environmental Geology, 38/1, 69-76, Berlin.

Kogovšek, J. \& M. Petrič, 2004: Advantages of longer-term tracing -- three case studies from Slovenia.- Environmental Geology, 47, 76-83, Berlin.

Kolbezen, M. \& J. Pristov, 1998: Površinski vodotoki in vodna bilanca Slovenije.- MOPHidrometeorološki zavod Republike Slovenije, p. 98, Ljubljana.

Placer, L., 1994/95: O zgradbi Soviča nad Postojno.- Geologija 37, 38, 551-560, Ljubljana.

Monitoring kakovosti izvirov, 2001-2002: http://www.arso.gov.si/podro cja/vode/poro cila_in_publikacije

PSO, 2002: http://www.gov.si/mop/podrocja/uradzaokolje_sektorokolje/porocila/stanje_okolja/odpadki.pdf

Rižnar, I., 1997: Geologija okolice Postojne.- Magistrsko delo, Naravoslovnotehniška fakulteta, Univerza v Ljubljani, Oddelek za geologijo, 1-78, Ljubljana. 


\section{POVZETEK}

Sedanje prehodno obdobje v slovenski zakonodaji o ravnanju z odpadki še vedno omogoča odlaganje, pa tudi širjenje odlagališč na t.i. rizičnih območjih, med katera spada tudi kras. Tako je na krasu trenutno aktivnih še 9 odlagališč (Sl. 1). Za vse je predvideno zapiranje in ustrezna sanacija, njihovo dejavnost pa naj bi prevzeli novi regijski centri za ravnanje s komunalnimi odpadki, postavljeni na bolj ustreznih lokacijah in z upoštevanjem sodobnih tehnoloških rešitev.

Na krasu so zaradi močne razpokanosti kamninske osnove in zato zelo dobre prepustnosti še posebej ogrožene podzemne vode. Od mesta vnosa se onesnaženje zelo hitro razširi v različne smeri tudi proti bolj oddaljenim kraškim izvirom, zaradi pretakanja $v$ podzemlju pa je smeri in značilnosti tega raztekanja težko natančno opredeliti. Sposobnost naravne filtracije je torej zelo majhna, obseg možnega negativnega vpliva pa zelo velik. Vir odpadne vode so deloma odpadki sami, večje količine pa so rezultat izpiranja škodljivih snovi s padavinami, ki pridejo v stik z odlagališčem.

Pravilnik o odlaganju odpadkov (Uradni list RS 5/00) zato kot del obratovalnega monitoringa predpisuje tudi meritve parametrov onesnaženosti podzemnih vod z nevarnimi snovmi, če so $\mathrm{v}$ vplivnem območju odlagališča. Upravljavec odlagališča mora najprej pridobiti ustrezen program, ki vsebuje prikaz hidrogeoloških razmer in tokovne mreže podzemnih voda, posnetek ničelnega stanja podzemnih voda, ciljne hidrogeološke cone, značilnosti vira onesnaževanja, opis izbire, izdelave in preizkušanja točk monitoringa, določitev parametrov monitoringa in pogostnosti njihovega merjenja. Program mora pred začetkom izvajanja potrditi tudi Ministrstvo za okolje in prostor.

Eno izmed trenutno še delujočih na krasu je odlagališče Stara vas pri Postojni. Namenjeno je odlaganju komunalnih in drugih nenevarnih odpadkov z območja občin Postojna in Pivka. Letno jih sprejme okrog 8500 ton. Projektirano je za sprejem približno $90.000 \mathrm{~m}^{3}$ kompaktiranih odpadkov. Ima urejen sistem zbiranja izcednih vod, ki jih preko kanalizacije odvajajo v centralno čistilno napravo Postojna. Površinske vode, ki niso v stiku z odpadki, so speljane v ponikalnico. Obratovanje odlagališča je predvideno do leta 2008, ko se pričnejo postopki zapiranja.

Širše območje odlagališča (Sl. 3) je zgrajeno iz zgornje krednih apnencev $\mathrm{K}_{2}^{2,3}$. Po podatkih OGK list Postojna (Buser et al. 1967) gre za siv rudistni apnenec s slabo določljivo radiolitno favno in neznačilno mikrofavno. Rižnar (1997) je te apnence uvrstil v Coniacij-Campanij $\mathrm{K}_{2}^{4,5}$. Po Rižnarju (1997) leži odlagališče v svetlo sivih do rjavih mikritnih apnencih z drobirjem rudistov in foraminiferami, ki se menjavajo s plastmi rudistnih lumakel, vmes so v zgornjem delu redke plasti pelagičnega apnenca, kalkarenita in gomolji roženca. Mlajši od krednih apnencev so bazalni sedimenti fliša (breča $\mathrm{s}$ kosi paleocenskega apnenca in vložki konglomerata in laporja - $\mathrm{Pc}_{2}, \mathrm{E}_{1}$ ). Po starosti sledi eocenski fliš (E - menjavanje laporja in peščenjaka). Najmlajši so kvartarni sedimenti, aluvij.

Da bi lahko ocenili značilnosti infiltracije vode in podzemnega pretakanja na območju odlagališča, smo teren še podrobno tektonsko-litološko kartirali v merilu 1:5000 (Sl. 3 in 4). Najmočneje izražena preloma sta dva. Severnejši prelom je, skladno z našim terenskim kartiranjem poleti 2005, določil že Rižnar (1997). Ta prelom poteka v dinarski smeri (SZ-JV) južno od Stare vasi, nekoliko severno od cestnega prehoda čez železniško progo ter severno od vrha Žerible. Prelom je subvertikalen z rahlim povijanjem $10-20^{\circ} \mathrm{v}$ horizontalni smeri. Zdrobljena cona ob prelomu ne preseže $2 \mathrm{~m}$. Prelom je vzporeden severnejšemu Predjamskemu prelomu (Placer 1994/95), ki poteka že izven slike 3. Južnejši prelom poteka po južnem robu odlagališča. Na zahodnem delu obravnavanega terena je subvertikalen, v bližini smetišča pa vpada za $70^{\circ}$ proti SV (20/70).

Poleg prelomov smo določili tudi več razpoklinskih, porušenih in razpoklinsko-porušenih 
sistemov po metodi Čarja (1982). Najbolj je zastopan razpoklinsko-porušen sistem 40-50/80-90. Južno od smetišča vpadajo razpoke pod kotom $80^{\circ}$ proti SV $(40 / 80,50 / 80)$, na območju smetišča pa so razpoke subvertikalne. Pravzaprav gre za $300 \mathrm{~m}$ široko razpoklinsko-porušeno cono dinarske smeri, ki je dobro prepustna za vodo in poteka prav čez postojnsko odlagališče. Poleg prevladujočih razpoklinsko-porušenih sistemov v dinarski smeri $(40 / 80,50 / 80,50,40)$ smo v bližini smetišča $\mathrm{v}$ manjšem obsegu določili tudi druge smeri porušenih con npr. 110/85, 100, 140/80, 180.

Opisana geološka zgradba se odraža tudi v hidrogeoloških značilnostih. Zaradi majhne debeline prsti, dobro razvitih razpoklinskih in porušenih con, dobre zakraselosti in posledično zelo dobre prepustnosti se padavinska voda hitro infiltrira v podzemlje. Tok vode skozi nezasičeno cono je hiter po primarnih drenažnih poteh, del vode in tudi v njej raztopljenih snovi pa se lahko dalj časa zadržuje $\mathrm{v}$ slabše prepustnih conah. $\mathrm{V}$ zasičeni coni se podzemna voda pretaka večinoma po razširjenih razpokah in kraških kanalih $\mathrm{v}$ različnih smereh proti izvirom na obrobju. Na osnovi opravljenih sledilnih poskusov sklepamo na odtekanje proti izvirom na Planinskem polju (Malenščica, Unica, Škratovka) in v Rakovem Škocjanu (Kotliči, Prunkovec) ter proti kraškim izvirom ob Pivki (Fužina pri Stari vasi), pa tudi proti izvirom Vipave v Vipavski dolini (Sl. 2). Ugotovljene so bile velike hitrost pretakanja podzemne vode $(0,2-0,7 \mathrm{~cm} / \mathrm{s})$. Vse to kaže na dobro prepusten, odprt vodonosnik s kraško-razpoklinsko poroznostjo. Najbolj zanimivi so rezultati sledenja na Počku (Kogovšek 1999, Kogovšek et al. 1999, Kogovšek \& Petrič 2004), kjer je bil uranin injiciran na površju v skalno dno vrtače in zato lažje potegnemo vzporednice $\mathrm{z}$ razmerami odtekanja izcednih vod $\mathrm{z}$ odlagališča. Sledilo se je najprej pojavilo v izviru Fužina, nato v izvirih Malenščice, najkasneje pa zaradi največje oddaljenosti v izvirih Vipave. Za izdelavo načrta monitoringa je zanimiva ugotovitev, da je zakasnitev pojava sledila za povečanjem pretoka od pol dneva do nekaj dni.

Podatkov načrtnega merjenja kakovosti kraških vod na vplivnem območju odlagališča je zelo malo, zato je potreba po vzpostavitvi monitoringa še toliko večja. Glede na pomen izvirov je predlagan monitoring na izvirih Malenščice in Vipave, ki sta zajeta za regionalno oskrbo s pitno vodo. Odlagališču najbližji in z njim zanesljivo povezan je vodni tok v jami Fužina oz. občasni izvir iz te jame. Kot točka monitoringa izven vpliva odlagališča pa je najbolj primerna Matijeva jama na Palškem jezeru. V skladu z zakonodajo je na vseh točkah predlagan osnovni monitoring štirikrat letno ob različnih hidroloških pogojih (v poletnem sušnem obdobju, po prvih jesenskih padavinah, ob visokih jesenskih vodah, ob spomladanskem naraščanju pretokov). Poleg tega pa je zaradi specifičnih lastnosti kraških vodonosnikov predlagano še podrobno spremljanje značilnega jesenskega vodnega vala. Fizikalni ter osnovni in indikativni kemični parametri, ki jih je potrebno spremljati v okviru monitoringa, so določeni s Pravilnikom o monitoringu onesnaženosti podzemnih vod. Poleg kakovosti pa je predvideno tudi merjenje izdatnosti. Pretoke Malenščice in Vipave redno meri Agencija RS za okolje, za spremljanje režima v jamah Fužina in Matijeva jama pa predlagamo postavitev naprav za zvezno spremljanje nihanja nivoja podzemne vode. Predvidena je stalna kontrola ustreznosti monitoringa, medsebojna primerjava dobljenih podatkov pa bo omogočila povečanje njegove učinkovitosti. 
